\title{
FIRST RECORD OF ARMASCIRUS JASMINE BASHIR, AFZAL\& KHAN (ACARI: PROSTIGMATA: CUNAXIDAE) IN EGYPT
}

\author{
FAWZY, M.M.H., A.M. KHALIL and A.A.M. ABD ALLAHA
}

Fruit Mite Dept., Plant Protection Research Instute , ARC, Dokki, Giza,Egypt

(Manuscript received 5 August 2014)

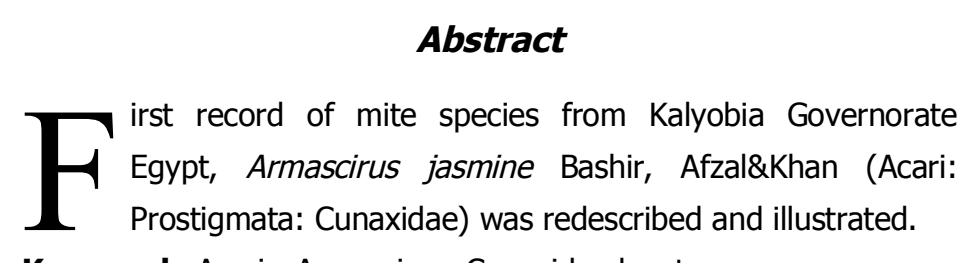

Key words:Acari : Armascirus, Cunaxidae key,taxonomy

\section{INTRODUCTION}

Family Cunaxidae are small(300-1000 mm) predatory mites found in a different habitats including, leaf litter soil, open rocks, agriculture fields and stored products Thor, 1902 (Den Heyer 1977;; Quilici et al. 1997; Sepasgosarian 1984; Smiley 1992; Walter 1999; Zaher et al .1975). They play an important role in biological control of some insects, scales, mites and nematods (Chaudhri et al.1979; Ewing\&Webster1912; Walter\&Kaplan1991).Cunnaxid mites are easily recognized by their spined palpi (except Bonzinae ) and diamond -shaped body (Krantez\& Walter 2009). The genus Armascirus was erected by Den Heyer (1978), who also gave a new taxonomical system and examined the systematics of the family cunaxidae. Later, the monograph presented more detailed Knowledge, including a new classification and more new taxa.

Since then new cunaxid species have been described from Asia (Muhammad\& Chaudhri 1991; Bashir\& Afzal 2005; Bashir et al.2008; Corpuz-Raros 1995, 2008; Corpus-Raros\& Gruezo 2007) and Europe (Kaluz 2009)

Most significantly for Armascirus spp. several new species of this genus were described from the Neotropical region (Den Heyer\&Castro 2008a,2008b,2012) and several species previously placed in other genera (Michocka 1982) were moved into Armascirus

Recently, Skvarla\& Dowling (2011) brought together the knowledge on this genus and along with a new species description, Presented a key to adults of Armascirus of the world Kaluz\& Vrabe (2013) they described two new species Armascirus fendai \& A. masani and a world key with 36 species of genus Armascirus. 
In Egypt same studies were carried out concerning the occurrence of biology and morphology of different cunaxid species (Zaher et al., 1970; Nassar,1976; ElBishlawy\& Rakha,1983; Zaher,1986.)

\section{MATERIALS AND METHODS}

The specimens studied were collected from soil and debris under cotton cultivars near Kaha research station, Kalyobia Governorate, isolated in tullgren photoelectric, cleared in nesbitte's fluid and mounted in Hoyer's medium. The drawings were carried out with light microscopy and camera lucida. All measurements stated in micrometers $\mathrm{mm}$ ). Body length was measured from the anterior margin of the pronotal dorsal shield to the caudal margin of pronotal shield. The dorsal setal notation follows the more generally accepted nomenculature of. The scale in all figures represents 100 $\mathrm{mm}$.

\section{RESULTS AND DISCUSSION}

\section{GENUS ARMASCIRUS Den Heyer, 1978:}

The main features separating the genus Armascirus from other genera of the subfamily cunaxyinae are Palpal segment II(basifemur) with a simple dorsal seta; palpal segment III(Telofemur) with a spine-like dorsal seta;apophaysis present on palpal segment IV(genu); the female palp with a median spine - like apophysis on segment III, wich is lacking in the males. Dorsal plates reticulated, the dorsal chaetotaxy includes two pairs of fine setaes trichobothria (vi and sce), the posterior pair (sce) is the longest, six pairs of tactile setae in dorsocentral and three pairs of dorso-lateral series. Anal region with a pair of anal setae and two pairs of para-anal setae. Chaetotaxy of telofemora I-IV: 4 sts (simple tactile setae) - 4 sts- 3 sts, ,1ms (micoseta) -3sts, $1 \mathrm{~ms}$

\section{Armascirus jasmine Bashir,Afzal\&Khan}

Differential diagnosis Armascirus jasmine looks like A. akhtari Bashir, Afzal\& Khan in having hystirosomal latiral reticulated shields and long apophises on palp genu but differs in, venter with 6 pairs of simple setae between coxa II and genital region in $A$. akhtari while in $A$. jasmine it has 7 pairs of ventral setae. Destances between basis of c1-c1 20 times the length of $\mathrm{c} 1$ in $A$. rafalskii while in $A$. jasmine $\mathrm{c} 1$ longer, the distance between the bases of $\mathrm{c} 1-\mathrm{c} 1$ less than 10 times the length $\mathrm{c} 1$. Also $A$. jasmine looks like $A$. asghari Bashir\&Afzal in having 7pairs setae between coxae II and genital region while differs in $A$. jasmine has basifemora I-IV with 5-5-3-2 setae;genu I with 7 setae while in $A$. asghari basifemora I-IV with 4-5-4-2 setae;genu I with 8 setae. 
female Description- idiosomal length 395mm, width 279mm - Dorsum(fig.1.) Dorsum propodosoma with a reticulate subrectangular shield with dimentions $229 \& 125 \mathrm{~mm}$. Propodosomal shield reaching to anterior region of hysterosoma ,bearing a pair of anterior(vi) and posterior (sce). Setae trichobothria with length 218 \&333 mm respectively and also 2 pair of tactile setae (ve and sci with length 17\&10 $\mathrm{mm}$. Distance between bases of vi-vi and sce-sce $106 \mathrm{~mm}$ and $145 \mathrm{~mm}$. Propodosomal separated from hysterosoma by fine striae. circula fine stria $r$ around the lateral platelets which located lateral of setae sce and c2 also fine stria between e1-e1.

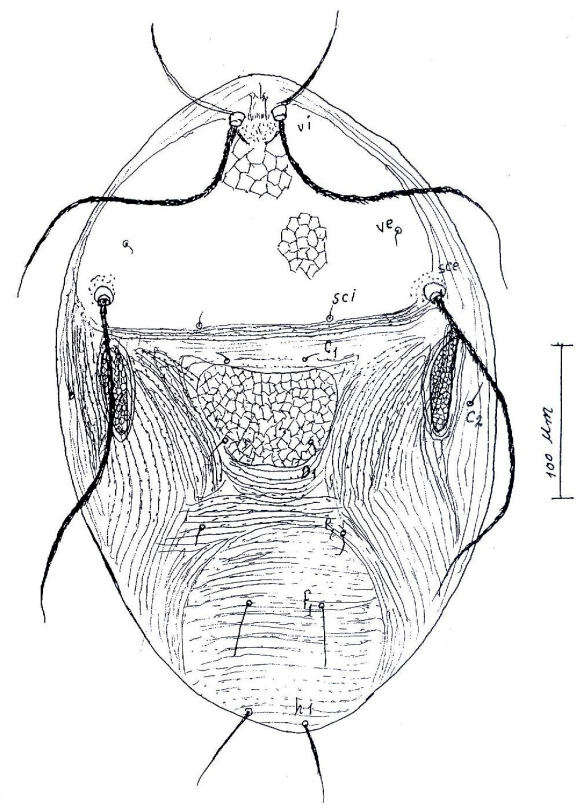

Fig 1. Dorsum of Armoscirus jasmine

Hysterosoma with reticulate subrectangular hysterosomal median shield with dimentions; long base in the front with $89 \mathrm{~mm}$, short base posteriorly $45 \mathrm{~mm}$ and the distance between them $69 \mathrm{~mm}$ carrying the dorsal one pair of setae(d1) with length 13 $\mathrm{mm}$. A pair of lateral reticulated platelets with length $83 \mathrm{~mm}$.

Six pairs of tactile dorsal setae present on hysterosoma the first four pairs, $\mathrm{c1}, \mathrm{c2}$, D1and e1 setae with length $8,8,13$ and $27 \mathrm{~mm}$ respectively. Distance between bases of setae ci,ci about $58 \mathrm{~mm}$ less than 10 times the length of setae $\mathrm{c} 1$. The longest two pairs of dorsal setae are $\mathrm{f} 1, \mathrm{~h} 1$, with length $35 \& 38 \mathrm{~mm}$ respectively.

Distance between bases of setae c1-c1 about 7 times length $\mathrm{c1}$; d1-d1 about 7 times length $\mathrm{d} 1$; e1-e1 about 2 times longer e1; $27 \mathrm{~mm}$

Distance e1-e1 1.5 equal $95 \mathrm{~mm}$ is $\mathrm{f} 195 \mathrm{~mm}$, is $2-5$ times of length $\mathrm{f} 1$, length oh $\mathrm{h} 1$ $37 \mathrm{~mm}, 1.5$ times of distance h1-h1 


\section{Venter: (fig.2)}

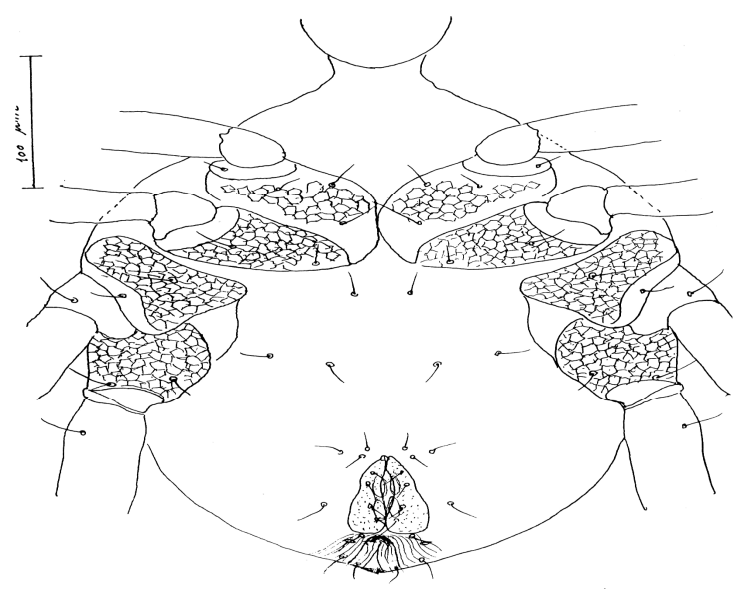

Fig 2. Ventrum of Armascirus jasmine

Venter with papillated striations. Coxal plates weakly sclerotized, coxae I-II and III-IV contiguous and finely reticulate, reticulation similar to those of dorsal shields, but three times smaller in diameter. Setal formula of coxae I-IV as follows: 3-2-2-2, there is one simple pair of setae between coxae II, 2 pairs of simple setae between coxae III, 3 pairs of simple setae anterior of genital plate and one pair of setae on each side of genital plate. Then between coxae II and genital plate 7 pairs of simple setae. Each valve of genital plate carrys 4 simple setae g1-g4 gradually increase in length from anterior to posterior and also carrys two genital suckers genital plate oval in shipe.

Anal setae (a) one pair, paranal setae (pa) 2 pair's posterior of genital plate (fig.2)

\section{Gnathosoma (fig.3)}

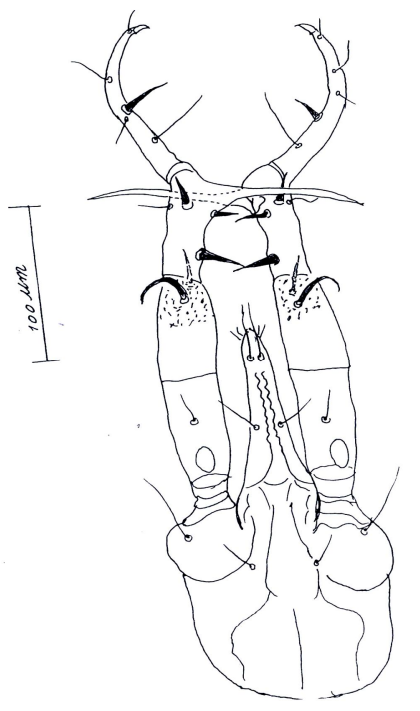

Fig 3. Gnathosoma and Hypostom of Armascirus Jasmine

Fig 5. Palp of Amascirus jasmine 
Ganthosoma 435 long and 112 wide. Hyposoma papillate, subrectangular in shape and cone-shaped distally $239 \mathrm{~mm}$ in length and $112 \mathrm{~mm}$ in width; with 4 pairs simple hypognathal setae (hg1-hg4) 16-19-12 and $48 \mathrm{~mm}$ in length respectively, and two pairs adorsal setae (fig3).

Palp (fig 5) segmented, all segments papillate, measuring $363 \mathrm{~mm}$ chaetotxy of palp as follow: trochanter none basifemur with one simple setae, telofemur with one bend apophasis and one spine setae; genu with one longtriangular apophasis with 75 $\mathrm{mm}$ length, 3 spine setae and one simple setae; tibiotarsus bend with $115 \mathrm{~mm}$ in length terminating in a small clow, with 4 (1 long-3 small) simple setae, and one thick, stout spine -like setae (fig.3)

Chelicera : ( fig 4) $170 \mathrm{~mm}$ long, terminating in a clow dorsal and ventral sides with lobes, with one dorsolateral simple setae (fig. 5).

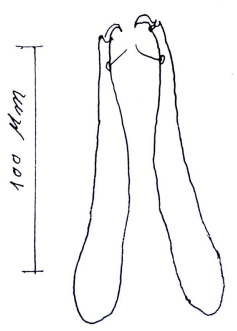

Fig 4. Chelicera Fig 5. Palp of Amascirus jasmine

Legs: (fig.6): Legs I-IV measuring (from trochanter base to the tip of tarsus) 469,364,427 and of Armascirus kaha 510mm respectively. All legs papillate, tarsiI-IV long slender and attenuated. Terminating in conspicuous lateral bilobed flanges. Caetotaxy of legs I-IV as follows:Coxae:3-2-3-2, Trochanter :1-1-2-1,Basifemora :55-3-2, Telofemora :5-5-4-5, Genu :8-6-5-7, Tibia :6-5-5-4, Tarsi :20-20-11-11.

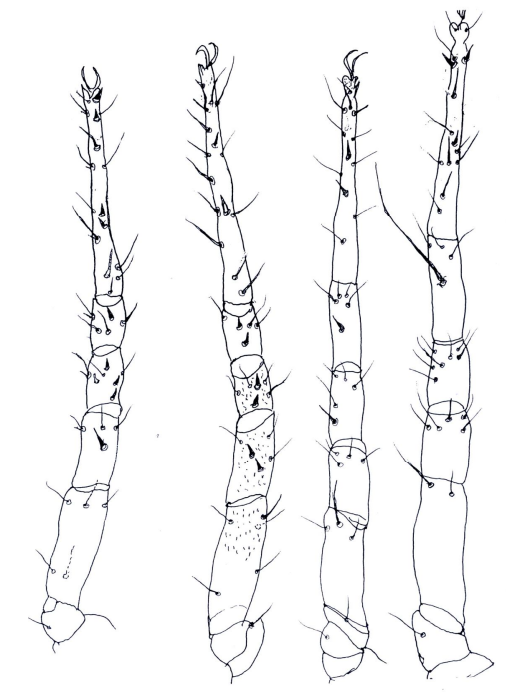

Fig 6. Legs of Armascirus jasmine 
Type: Holotype and paratype female collected from debris under cotton cultivars near Kaha research station in Qalyobia governorate, Egypt.

\section{REFERENCES}

1. Bashir,H.M. \& Afzal, M. 2005. Newcunaxid mites of the genus Armascirus from Punjab Pakistan. Pakistan J. Agric. Sci., 42,117-121.

2. Bashir,H.M. , Afzal, M.\& Khan, B.S. 2008. Genus Armascirus (Acari: Prostigmata: Cunaxidae) from Pakistan. Belgian J. Zool., 115-127.

3. Chaudhri, M.W., Akbar, S.\& Rasool, A. 1979. Studies on the predatory leaf Inhabiting Mites of Pakistan. Uni. of Agric., Faisalabad, Pakistan, 228 pp.

4. Corpuz-Raros, L.A. 1995. Philippine predatory mites of family Cunaxidae (Acari). 2. Genera Armascrirus Den Heyer and Dactyloscirus Berlese. The Philippen Agric.,78(2), 159-173.

5. Corpuz-Raros, L.A. \& Gruezo, W.S. 2007. Two new species of predatpry mites of family Cunaxidae(Acari) from Java, Indonesia. Asia Life Sci., 16(2), 175-181.

6. Corpus-Raros, L.A. 2008. Additional species of Cunaxidae and first report of subfamily Neobonzinae (Cunaxidae:Acari) from the Philippenes Asia Life Sci., 17(1), 71-89.

7. Den Heyer, J. 1977. A new genus Neoscirula (Cunaxidae: Prostegmata: Acari) from the Ethiopian region. J. Entomol. Soc. South Africa, 40(1), 73-86.

8. Den Heyer,J. 1978. Four new speciesof Armascirus gen.nov. (Prostegmata: Acari) from the the Ethiopian region. J. Entomol.Soc. South Africa, 41(2), 217-239.

9. Den Heyer,J.\& Castro, T. (2008a) A new a new cunaxid genus with a descriptions of tow new species from Brazil (Acari: Prostegmata: Bdelloidea: Cunaxidae). Zootaxa, 1731, 42-50.

10. . Den Heyer,J.\& Castro, T. (2008b) A new Neotropical genus of the family Cunaxidae (Acari: Prostegmata: Bdelloidea: Cunaxidae). Zootaxa, 1843, 35-46.

11. Den Heyer,J. \& Castro, T. 2012. new Neotropical cunaxine species(Acari: Prostegmata: Bdelloidea: Cunaxidae). Zootaxa, 3265, 22-44.

12. El-Bishlawy,S.M. \& M.A. Rakha. 1983. A new species mites pulaeus zaherii sp.n. from Rat Burrows in Egypt (Actinedidae: cunaxidae)Acarol,xxIV,fasc.4:373-375.

13. Ewing, H.E. \& Webster, R.L. 1912. Mites associated with the oyster-shell scale (Lepidosaphes ulmilinne).psyche, 19(4), 121-134.

14. Kaluz, S. 2009. Tow new palearctic mite species of the family Cunaxidae (Acari: Prostegmata). Zootaxa, 2198, 27-40.

15. Kaluz, S. \& Vrabec,M. 2013. Tow new species of Armascirus (Acari: Prostegmata: Cunaxidae)from Solvakia.J., Zootaxa, 3734(2): 141-155.

16. Krantz, G.W. \& Walter, D.E. 2009. A Manual of Acarology. Third edition. Texas tech University Press, Lubbock, Texas, 807 pp. 
17. Michocka, S. 1982. Tow new species of family Cunaxidae (Acari: Prostegmata) from Poland. Acarologya, 23, 327-332.

18. Muhammad, T. \& Chaudhri, W.M. 1991. Tow new cunaxid mites of the genus Armascirus (Acari: Cunaxidae) from Pakistan Entomologyist, 13, 50-55.

19. Nassar,O.A. 1976. Incidence of predaceous mites on fruit trees in North East of Delta with emphasis on Cunaxa setirostris (Hemann). MSc. Thesis Fac. Agrc. Cairo Univ. 91 pp.

20. Quilici, S., Kreiter, S., Ueckermann E.A. \& Vincenot D. 1997. Predatory mites (Acari) from various crops on Reunion Island. International Journal of Acaroloygy, 23(4), 283-291.

21. Sepasgosarian, H. 1984. The world genera and species of the family Cunaxidae (Actinedida: Acarida). Zeitschrift fur Angewandte Zoologie, 71, 135-153.

22. Smiley, S.F. 1992. The predatory mite family cunaxidae (Acari) of the world with a new classification. Indira Publishing House, West Bloomington, Michigan, 356 pp.

23. Skvarla, M.J. \& Dowling, A.P.G. 2011. Some new armascirine cunaxids(Acari: Prostegmata: Cunaxidae). J. Zootaxa, 3194: 1-34.

24. Thor, S. 1902. Zur Systematik der Acarinenfamilien Bdellidae Koch, 1842, Grube 1859, Eupodidae Koch, 1842 and cunaxidae Sig Thor, 1902. Verhandllungen der Kaiserlich-kongiglichen zoologish-botanischen Gesellshaft in Wien, 159-165.

25. Walter,D.E. 1999. Cryptic inhabitans of noxious weed: Mites (Arachnida: Acari) on Latana camara L. invading forests in queensland. Aust. J. Entomol., 38,197200.

26. Walter,D.E.\& Kaplan, D.T. 1991. Observations on Coleoscirus simplex (Acarina: Prostegmata), a predatory mite that colonizes greenhouse cultures of rootkont nematode (Meloidogyne spp), and a review of feeding behavior in Cunaxidae. Experimental and applied Acarology, 12 (1-2), 47-59.

27. Zaher, M.A. 1986. Survey and ecological studies on phytophagous, predaceous, and soil mites in Egypt. II A Predaceous and non-predaceous mites (Nile Valley and De) PL 480 Program USA Project No. EG-ARS-30. Grant No.FG-139.

28. Zaher, M.A., Soliman,Z.R. \& El-Bishlawy, S.M. 1975. Studies on population dynamics of soil predaceous prostigmataid mites in Giza, Egypt .Zeitschrift fur Angewandte Entomol., 79, 440-443.

29. Zaher, M.A., A.K. Wafa; M.M. Ali and A.H. Rasmy. 1970. Survey of mites associated with citrus trees in Egypt and Giza Strip, Bull. Soc. Entomol. Egypt L IV: 73-79. 


\title{
Armascirus jasmine Bashir,Afzal \&Khan تسجيل لاول مرة لنوع من عائلة Cunaxidae فى مصر
}

\author{
مجدى محمد حسين و عابدين محمود خليل وعادل امين محمد عبدالله
}

قسم اكاروس الفاكهة ، معهد بحوث وقاية النباتات مركز البحوث الزراعية ، جبرة مصر

تم اعادة رسم ووصف للنوع Armascirus jasmine Bashir,Afzal \&Khan من عائلة كتسجيل لاول مرة فى مصر بمحافظة القليوبية فى الاوراق المتحللة تحت شجيرات Cunaxidae - القطن تمناز انو اع جنس الارماسكيرس بوجودامتداد متغلظ فى الركبة لملمس ومتقاطع مع الامتداد

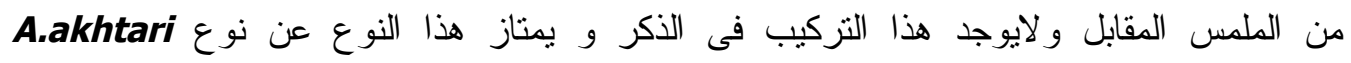
بوجودستة ازو اج من الثعيرات البطنية بين حرقفة الزوج الثانى من الارجل و الصفيحة التتاسلية بدلا من سبعة ازو اج فى الاختارى. 